\title{
Linking Real-Life Situation with Content of School Mathematics at Secondary Level: Exploring Current Practice and Challenge in Bangladesh
}

\author{
Sharmin Kabir ${ }^{1 *}$ Tahmina Khanam Jalali ${ }^{2}$ \\ 1. Assistant Professor, Institute of Education and Research, University of Dhaka, Bangladesh
}

2. Student of Master of Education in Academic Session 2017-18, Institute of Education and Research, University of Dhaka, Bangladesh

* E-mail of the corresponding author: sharmin ier@du.ac.bd

\begin{abstract}
Worldwide mathematics is considered as a subject in school curriculum which is intimately connected to students' daily life. However, it is disheartening that there are some level of disconnection between students' mathematics learning and the way it is applied to real-world. This study is conducted to explore the current practice and challenges in linking real-life situation with mathematical content at secondary level in Bangladesh, a country in transition from least-developed to developing status. Here multiple case study approach was followed under qualitative framework. Mathematics teachers of Grade 8 and their lessons were selected conveniently to explore how teachers were responding to the issues of practice and challenges in linking real-life situation and eventually promoted mathematical literacy in their lessons. Each teacher was considered as a case. Lesson observations, participant teachers' interview, FGD with students and document analysis had been used as instruments in the study. Thematic analysis was followed as the data analysis technique. In this paper, we briefly summarized our work in exploring current practice and challenges in Bangladesh in connecting real-world with the world of mathematics. This study finds that teachers emphasize on explaining mathematical concept in ways that make sense to students but practice in specific cases. Occasionally, students struggle with mathematical terminologies while teachers are unaware of it. Moreover, teachers find difficulties to connect some mathematical content with real-life situations because of the nature of content and during the lessons they rely on "teaching textbooks" due to time constraint. Both teachers and students in this study point out that textbook examples and problems are not interesting. Finally, this study finds that Grade 8 mathematics textbook, in limited cases, deals with "real" problems: problems that are typically placed in a "situation". The present study will thus provide insights to the teachers to improve their practice in order to make mathematics more significant and interesting to the students. This study will also notify the textbook writers to bridge between content and context to increase the effectiveness and quality of mathematics textbook by including more real-life oriented mathematical problems. Along with improved teachers' practice and quality textbook, this study will eventually provide opportunities for students to be engaged with mathematics in a more meaningful way and to finally develop their mathematical literacy at an expected level.
\end{abstract}

Keywords: Real-life situation, Mathematical literacy, Mathematisation

DOI: $10.7176 / \mathrm{JEP} / 12-3-19$

Publication date: January $31^{\text {st }} 2021$

\section{Introduction}

Mathematics is a critical tool for youth as they confront issues and challenges in personal, occupational, societal and scientific aspects of their lives (Organisation for Economic Co-operation and Development [OECD], 2017). However, in learning mathematics students usually do not realize why they have to learn it and that impacts their motivation and retention (Diggs, 2009). On the other hand, students' interest in mathematics increases when they understand the skills and how that skill is developed and connected to required mathematics competencies for performance (Mensah, Okyere \& Kuranchie, 2013, as cited in Arther, Owusu, Asiedu-Addo \& Arhin, 2018). It is emphasized that mathematical problem should be realistic so that learners can build their own mathematical concepts (Royal Ministry of Education, Research and Church affairs [RMERC], 1999). Increased stress on tasks that promote connections and applications of mathematics to real-world had been called for by researchers and reforms in curriculum frameworks in several countries since the 1990s (for example, National Council of Teachers of Mathematics [NCTM], 1989, 2000 cited in Cheng, 2013). 


\subsection{Statement of the problem}

In Bangladesh, one of the aims of school mathematics curriculum is to make learners acquired with mathematical logics, methods and skills; and to increase their abilities to apply them for solving problems concerning day to day activities and global affairs (National Curriculum and Textbook Board [NCTB], 2012. p. 8, translated by authors). In reality, $57.56 \%$ of mathematics teachers in Bangladesh, who have served for more than 10 years, are not naturally well conversant with existing curriculum (Bangladesh Bureau of Educational Information and Statistics [BANBEIS], 2008). Moreover, within the last consecutive years there are higher failure rates in mathematics subject in Secondary School Certificate (SSC) examination, after the completion of secondary education in Bangladesh (BANBEIS, 2008).

\subsection{Significance of the study}

There has been a variety of research on mathematics education in Bangladesh. Most of these studies focus on assessment system, teachers' training program or text book implementation. However, there is a void in extensive research in Bangladesh on developing mathematical literacy of secondary students' through tasks that promote connections and applications of mathematics to real-world. This study thus seeks to explore the current practice and challenges that teachers' face in Bangladesh in connecting mathematical content with real-life situation.

\subsection{Research questions}

The following research questions (RQ) are used for this study:

RQ1: What are the current practices in Bangladesh in linking real-life situation with mathematical content?

RQ2: What are the challenges that teachers face in Bangladesh to link real-life situation with mathematical content?

\subsection{Limitations}

This study has been conducted in small scale and only in the capital city of the country. Further research can be done in large scale including rural and other urban areas for a deeper understanding about current practice and challenges in bridging between content and context for developing mathematical literacy of secondary students' in Bangladesh.

\section{Literature Review}

\section{Real-World Mathematical Problems}

Palm (2008) indicates some level of disconnection between students' mathematics learning and the way it is applied to real-world. Research reveals this disconnection cause struggles by students' in understanding mathematics where some blame, for this disconnection, the mathematical contents these students are required to learn while others blame the educational approach taken by teachers (White-Clark, DiCarlo \& Gilchriest, 2008). Education standards in many countries emphasize the vital importance of bridging school mathematics with reallife situations (Larina, 2016). In consequence, the teaching of mathematics is made interesting to students when teachers are ready to connect mathematical concepts to real-world problems (Arthur et al., 2018). Real-world problems are also referred to as everyday problems (OECD, 2013), realistic problems (Cooper \& Harries, 2005; Gainsburg, 2008; Pais, 2013), applied tasks (Palm, 2006) and modeling tasks (Blum \& Ferri, 2009; Frejd, 2012). Accordingly, there are multiple definitions of real-world mathematical problems which, in general, suggest that different characteristics may be used in theoretical models of such problems. In reviewing literatures for the present study, three different aspects were investigated initially in connecting real-world with the world of mathematics: (1) components of the connection (2) outcome of the connection and (3) classroom tools for the connection. Various themes with indicators were then identified in this study as theme locates something significant about the information in relation to the research question, and represents some level of comparable response (Braun \& Clarke, 2006).

\subsection{Components of Connecting Real-World with the World of Mathematics}

\subsubsection{Language in Mathematics}

In several studies (for example, Meiers, 2010), we observe that using everyday language is the first indicator of real-world mathematical problem in relation to the theme of language in mathematics. Students at all levels need opportunities to express mathematical terms in ways that make sense to them (Adams, Thangata \& King, 2005). It is argued that everyday language plays a vital role in learning mathematics and mathematical problems should describe situations with the help of words, symbols and events that people come across every day (Meiers, 2010). 
The use of everyday language as the first characteristic of real-world mathematical problems implies two unavoidable processes: mathematical modeling and interpretation (Larina, 2016). Likewise, teachers need to encourage students to communicate about what the teacher is trying to teach and what they are trying to learn (Gough, 2007).

\subsubsection{Context and Situational Relevance}

The second component of a real-world mathematical problem is the context and situational relevance. The incorporation of context in problems has been highly recommended by recent reform documents and mathematics curricula around the world (for example, OECD, 2013). The PISA (Program for International Student Assessment) framework in OECD (2003) for developing real-world mathematical problems suggests four different contexts: personal, educational \& occupational, public and scientific which are described as follows:

- Personal Context: It is assumed that such a context would be of immediate and direct personal relevance to many young kids.

- Educational \& Occupational Context: These contexts include problem situations that students might confront while at school (artificially designed for teaching and practice purposes), or problems that would be met in a work situation.

- Public Context: Public contexts are those situations experienced in one's day-to-day interactions with the outside world.

- Scientific Context: The stimulus for this context usually presents scientific data, for example, data on level of carbon dioxide emissions for several countries, and the problem might ask students to interpret and make use of the data presented.

\subsection{3 'Mathematisation': The Problem-Solving Process}

The third and final component of real-world mathematical problem involves problem-solving process or the process of 'mathematisation' as it is called in the PISA framework in OECD (2003) of mathematical literacy. OECD (2009) describes 'mathematisation' as a circular process with the subsequent five main features of the problem:

1. Real-world setting of the problem.

2. Consistent organization of the problem with mathematical concepts and identification of relevant mathematics.

3. Transformation of the real-world problem into a mathematical problem.

4. Solving the mathematical problem.

5. Making sense of the mathematical solution in terms of the real-world situation.

These five aspects were then clustered into three phases, as follows, according to general features of mathematical problem-solving approaches in OECD (2009) and then summarized as Figure 1 in Franchini, Lemmo \& Sbaragli (2017):

Phase 1: Understanding the question (e.g. dealing with extraneous data), which is called "horizontal mathematisation".

Phase 2: Sophistication of problem-solving approaches, which is called "vertical mathematisation".

Phase 3: Interpretation of mathematical results that means, linking mathematical answers to the given context. 
HORIZONTAL MATHEMATISATION

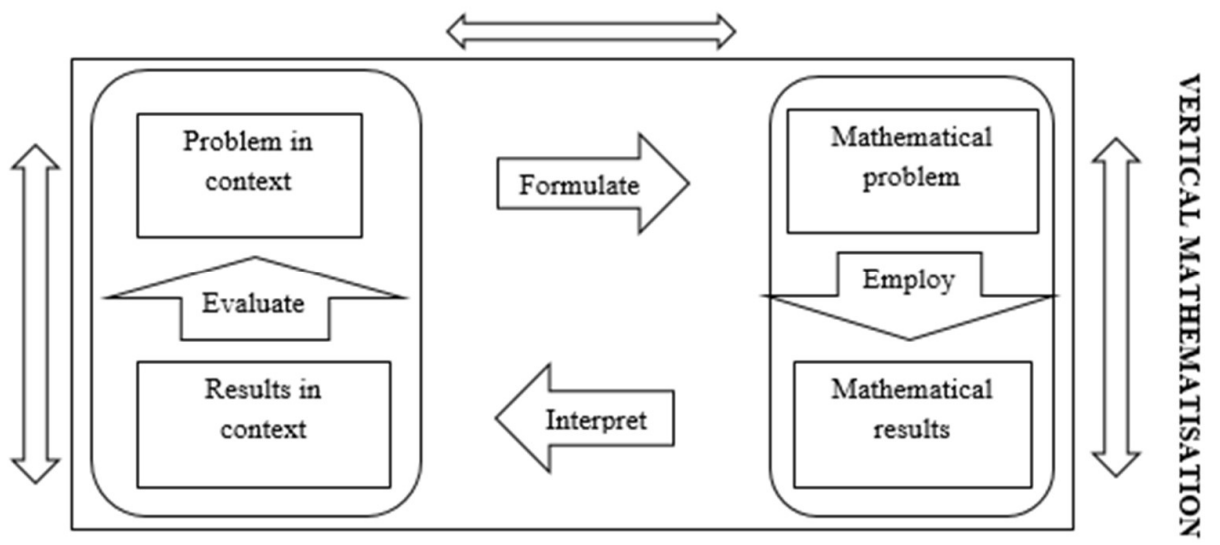

REAL WORLD

Figure 1. 'Mathematisation' Cycle (Franchini, Lemmo \& Sbaragli, 2017)

\subsection{Outcome of Connecting Real-World with the World of Mathematics}

\subsubsection{Developing Mathematical Literacy}

PISA in OECD (2003) defines mathematical literacy as "an individual's capacity" for identifying and understanding "the role that mathematics plays in the world" and, in particular, emphasizes on making "wellfounded judgments" in using mathematics "in ways that meet the needs of that individual's life" as a concerned citizen. Briefly, mathematical literacy is the capability of dealing with "real" problems: problems that are typically placed in a "situation" (Burkhardt, 2008). While developing mathematical literacy, students have to "solve" a true world problem requiring them to use the skills and competencies they acquired through schooling and life experiences (Cohen, 2001). Later, Burkhardt (2008) investigated a number of PISA tasks where the task labeled as Primary Teachers, provided in Table 1, was one of those.

Table 1. An Example of PISA Task (Burkhardt, 2008)

\section{PRIMARY TEACHERS}

In a country with 60 million people, about how many primary school teachers are going to be needed? Try to estimate an answer using your own everyday knowledge about the world. Write an explanation to establish your answer, stating any assumptions you make.

Burkhardt (2008), finally, identifies that mathematical literacy involves (a) "complex reasoning" (as logical and systematic thinking) and (b) linking models of the situation to data - which Steen (Ed.) (2002) describes as the "sophisticated use" of elementary mathematics.

\subsection{Classroom Tools for Connecting Real-World with the World of Mathematics}

\subsection{1 'Making Better Use' of Mathematics Textbook in Linking Real-Life Situation}

Textbooks are designed for the purpose to help teachers to organize their teaching (Johansson, 2006) and in attempting to specify how classroom lessons can be structured with appropriate exercises and activities (Lockheed, Vail \& Fuller, 1986). Conversely, if mathematics textbooks are monotonous and uninteresting then it is an obstacle for students learning (Johansson, 2006). Educational reform has urged to transform the function of textbooks' from 'controlling teaching' to 'serving for teaching' (Guo, 2001). The use of textbooks by teachers in mathematics lessons are thus divided into three levels according to the framework of Nicol and Crespo (2006). They are "adhering", "elaborating" and "creating". Literally, "adhering" usage indicates considering textbooks as "an authority" to decide what to teach and how to teach. During this level of usage, teachers always make no adjustment 
or modification on textbooks. In "elaborating" usage of textbook, teachers will take advantage of other sources, in addition to considering textbook as "a guide", to amplify the questions, tasks and exercises given in textbooks. In "creating" usage of textbook, teachers keep a critical eye on textbooks and consequently, locate the intention and limitations of the textbooks and finally, optimize teaching structures and pedagogical sequences including teaching system by setting up appropriate problems. It is important to note that, with the advancement of mathematics curriculum reform, teachers are strongly urged to have decreased dependence on textbook and to change their mind-set from "teaching textbooks" to "making better use of textbooks" (Qi, Zang \& Huang, 2014). This leaves teachers with the scope of creating favorable mathematics learning environment in linking real-life situation and to promote mathematical literacy of secondary students.

\subsubsection{Mathematics Teaching in Linking Real-Life Situation}

Students have to be actively engaged in learning rather than just being listeners and observers in their classes (Jameel \& Ali, 2016). Teachers attempt to simply pour information into children's minds, as in traditional way of teaching, is not anticipated in current educational reforms. Rather, children ought to be given confidence to discover their world, find out knowledge, consider and think critically with vigilant supervision and significant guidance of the teacher (Eby, Herrel \& Jordan, 2005). Research strongly suggests that students have to build their own understanding of every concept of mathematics and thus the main responsibility of teaching is not explaining, lecturing or attempting to convey mathematical knowledge, but creating situations for students to promote their mental structures (Lessani, Yunus \& Bakar, 2017).Teachers role in making mathematics meaningful and engaging students to form their own interpretation of evidence and to submit it for review are emphasized since effective teaching method helps students to develop a wide range of complex mathematics structures and to gain the capability of solving variety of real-life problems (Tarmizi \& Bayat, 2012).

In linking real-world with the world of mathematics six themes with several indicators identified in this study are briefly summarized in Table 2 . Among the themes identified in present study, three were related to the components of the connection between the real-world and the world of mathematic, two were in relation to the classroom tools for the connection and one was related to the output of the connection.

Table 2. Themes and Indicators in Linking Real-Life Situation with Content of Mathematics

\begin{tabular}{|c|c|}
\hline Themes & Indicators \\
\hline $\begin{array}{l}\text { Making Language Meaningful to } \\
\text { Students } \\
\text { (Component of Connection) }\end{array}$ & $\begin{array}{l}\text { - Using everyday language in mathematics } \\
\text { - } \quad \text { Explanation of difficult (or unfamiliar) mathematical terms }\end{array}$ \\
\hline $\begin{array}{l}\text { Contextualization and Situational } \\
\text { Relevancy of Mathematical Problems } \\
\text { (Component of Connection) }\end{array}$ & $\begin{array}{l}\text { - Immediate and direct experiences in one's day to day interaction with the outside world } \\
\text { - } \\
\text { Problems are related to application of mathematics to the situation of natural world } \\
\text { faced by many young kids at school, work station or in family }\end{array}$ \\
\hline $\begin{array}{l}\text { 'Mathematisation' } \\
\text { (Component of Connection) }\end{array}$ & $\begin{array}{l}\text { - } \text { Identifying and organizing problem based on real-world setting with the mathematical } \\
\text { concept } \\
\text { - } \quad \text { Transforming real-world problem into a mathematical problem } \\
\text { - } \quad \text { Solving the mathematical problem } \\
\text { - } \quad \text { Making sense of the mathematical situations in terms of the real situation }\end{array}$ \\
\hline $\begin{array}{l}\text { Developing Mathematical Literacy } \\
\text { (Output of Connection) }\end{array}$ & $\begin{array}{l}\text { - } \quad \text { Students are involved in complex reasoning } \\
\text { - } \quad \text { Students link models of the situation to data }\end{array}$ \\
\hline $\begin{array}{l}\text { 'Making Better Use' of Mathematics } \\
\text { Textbook } \\
\text { (Classroom Tool for Connection) }\end{array}$ & $\begin{array}{l}\text { - } \quad \text { Shift in use of textbook from 'controlling teaching' to 'serving for teaching' } \\
\text { - } \quad \text { Teachers' adjustment or modification on textbooks, if needed } \\
\text { - } \quad \text { Taking advantage of other sources to amplify the questions, tasks and exercises given in } \\
\text { textbooks } \\
\text { - Teachers' critical eye to locate intention and limitations of textbook }\end{array}$ \\
\hline
\end{tabular}




\begin{tabular}{|c|cl|}
\hline Mathematics & $\bullet$ & Teaching methods make mathematics meaningful to students \\
Teaching & $\bullet$ & Students are given confidence to discover their world \\
(Classroom Tool for Connection) & $\bullet$ & Creating situations for students to promote their mental structures \\
& $\bullet$ & Students think critically with vigilant supervision and significant guidance of the teacher \\
& $\bullet$ & Students form their own interpretation of evidence and submits it for review \\
$\bullet$ & Students gain the capability of solving variety of real-life problems
\end{tabular}

\section{Methodology}

\subsection{Study areas and period of time}

The study area was located in Dhaka, the capital city of Bangladesh. The selected cases were from four neighboring schools of University of Dhaka. This study required just about 4 months.

\subsection{Nature of the study}

Qualitative research is best suited to address a research problem in which researcher does not know the variables and need to explore more from participants through exploration (Creswell, 2012). While exploring the current practices and challenges in linking real-life situation with mathematical content in Bangladesh, qualitative approach was considered as an appropriate option for the study. Case study was used as research design. Four mathematics teachers of Grade 8 from four different schools were chosen conveniently as the cases. Three lessons of each of the cases were observed. According to Bell (2005), observation can be useful in discovering whether people do what they say and how they behave in the way. In each case, a total of six Grade 8 students (among them 3 were girls \& 3 were boys), whose lessons were observed, were selected purposively for Focus Group Discussion (FGD).

\subsection{Procedures of sampling}

Table 3. Sample and sampling of the present study

\begin{tabular}{|l|l|l|}
\hline \multicolumn{1}{|c|}{ Activity } & \multicolumn{1}{c|}{ Sample } & \multicolumn{1}{c|}{ Sampling technique } \\
\hline Lesson observation & Mathematics lesson (Grade 8) & Convenience sampling \\
\hline Focus group discussion & Students of Grade 8 & Purposive sampling \\
\hline Document analysis & Students notebooks & Purposive sampling \\
\hline Teachers interview & Mathematic teachers (Grade 8) & Convenience sampling \\
\hline
\end{tabular}

\subsection{Data collection methods}

In this study, data was collected through lesson observation, interview schedule, FGD and documents analysis. A total number of twelve lessons of Grade 8 were observed. Four FDGs with students of observed lessons and interviews with four participant teachers were conducted along with analyzing class work and homework notebooks of the participant students as documents and records. Themes and corresponding indicators of Table 2 were used to develop observation checklist and questionnaires for interviews and FGDs. Semi-structured interview (Note 1) of participant teachers after observing all three of their lessons were conducted for both RQ1 and RQ2. In addition to interviews, lesson observations, FGDs with students and document analysis were conducted for RQ1. In FGDs, students discussed about teachers' current practice during lessons in linking real-world with the world of mathematics as well as their own experiences and expectations from mathematics lessons.

\subsection{Data analysis}

Thematic analysis was used for this study. According to Braun \& Clarke (2006), thematic analysis is a method which is used for identifying, analyzing, and reporting patterns (themes) within data. Collected data was analyzed on the basis of six themes with their indicators identified in the present study.

\subsection{Ethical consideration}

To collect data, request letters were at first sent to the principals (head teachers) of the concerning schools. Consent from participating teachers and students were taken before conducting the interview, observation and FGD. The 
objective and goal of the study was shared with the participants as it is necessary to inform participants to gain support from them (Creswell, 2012). Participant teachers and students willingly cooperated with the study.

\section{Results and Discussions}

In this section, we briefly summarize our work in exploring current practice and challenges in Bangladesh in linking real-life situation with mathematical content. We have identified a number of issues and learned many lessons while conducting this research. Although some issues and lessons may be unique to the context of Bangladesh, we believe many are applicable across countries. On the basis of qualitative review of lesson observation, participant teachers' interview, FDG with students and analysis of documents the following findings are shared in this paper.

\subsection{Teachers emphasize on "making language meaningful to students" but practice only in specific cases}

All of the four teachers, in their interviews, emphasized that mathematical term should be expressed in ways that make sense to students. They also claimed their support in explaining difficult or unfamiliar words in mathematics lessons as regular. However, only in specific arithmetic (profit, loss \& interest related) lessons it was observed that all of the teachers explained the mathematical terms such as "cost price", "retail selling price" in ways that make sense to students. In particular, Teacher C gave an example of "khuchra-bikreta" ('retail seller' in textbook language) as "mudi-dokander" (a word from everyday language in Bangladesh) and doing so easy language was used for students understanding. Document analysis in all four cases also suggests that generally, there were no explanations of unfamiliar words during mathematics lessons. For instance, students in case 1 wrote "Fibonacci" in their notebook from previous lesson but did not know that it was 'name' of a mathematician.

\subsection{Students struggle with mathematical terminologies while teachers are unaware of it}

Teachers, usually, were not concerned in explaining unfamiliar terms used during the lessons of algebra and geometry. Teacher A mentioned in interview that there was no difficult or unfamiliar term in all three of the lessons observed which included two on algebra (use of algebraic formula and middle term factorization) and one on geometry (diagonals of a parallelogram bisect each other). However, FGD with students of these lessons revealed that they expected simplification of the unfamiliar words used during those lessons such as 'middle term factorization', 'diagonal' and 'bisection'. In all the four cases, students in FGD expressed their view that if difficult words were explained, it would had been easier for them to solve the mathematical problem. While claiming this, in Case 4 students' provided an example as an evidence from their class work notebook which had the explanations of the unfamiliar word, 'Pie chart', as "it is round shaped, it looks like a food called 'PIE', so it is called pie chart."

\subsection{Teachers face difficulties to relate mathematical content with real-life situation due to the nature of content}

All the teachers in their interviews agreed that real-life situation is important for students understanding and motivation, however, from class observation, FGD and document analysis it was evident that teachers used reallife related examples only in particular arithmetic lessons. When being asked about their practice in connecting real-life situation with mathematical contents in their lessons, teachers identified that most of the time they faced difficulties in connecting real-life situation with algebra and geometry because of the "nature of content". Moreover, Teacher B viewed that it was not necessary to link real-life situation with every mathematical contents, whereas others disagreed with this opinion in their interviews. On the other hand, connection of real-life situation with every mathematical content was expected by students in all FGDs.

\subsection{Textbook problems were not typically placed in a "situation" and hence were not "real" to students}

While observing the lessons, it was identified that in Grade 8 textbook in Bangladesh, generally, problems were not related to application of mathematics to the situation of natural world faced by many young kids at school, work station or in family, for example, as seen in PISA Task: PRIMARY TEACHERS in Table 1. Students were not engaged in transforming real-world problem into a mathematical problem and thus had limited opportunity for 'sophisticated use' of mathematics. A particular arithmetic topic (on profit, loss \& interest) and concept on 'Data \& Information' were based on real-life settings. Generally, in mathematics lessons the opportunity provided by the textbook for students to make sense of the mathematical situations in terms of the real situation were not observed and consequently, there were limited scopes for immediate and direct experiences in students' interaction with the outside world. For instance, we have described earlier that Teacher A in a geometry lesson was proving the theorem the diagonals of a parallelogram bisect each other. In textbook, this problem, like most of the others, was not typically placed in a "situation" and hence, was not "real" to students.

\subsection{Teachers rely on "teaching textbooks" due to time constraint}


Lesson observation revealed that generally, teachers rely on mathematics textbook in "adhering" level of usage with no adjustment or modification on textbooks. In no cases teachers took advantage of other sources (such as technology) to amplify the questions, tasks and exercises given in textbooks. In rare cases, (only once in Case 4) teachers kept a critical eye on textbooks to identify limitations and act accordingly in order to optimize learning as in "creating" level of usage of textbook. In Case 4, students in FGD identified that Teacher D used examples beyond textbook only on the topic 'Profit' where examples related to banking system were provided by the teacher. Students expressed their preferences on these types of examples. Except Teacher B, all, however, agreed that textbook examples are not enough for students learning but the pressure to complete syllabus within a short time prevailed them to provide problems and examples beyond textbook. However, Teacher B strongly argued that textbook examples were enough for students' learning.

\subsection{Both teachers and students found textbook examples and problems uninteresting}

Both teachers and students expressed their opinion that textbook examples and problems were 'not interesting'. In addition to that, Teacher D addressed textbook problems and examples as 'simple' and 'traditional'. Students found very few examples and word problems in textbook interesting. They specifically mentioned problems in 'Data \& Information' topic were interesting since these were related to 'sports'.

\subsection{Non-observance of teaching in making mathematics meaningful to students}

It was observed that, without any exception, students were listeners and observers in their mathematics lessons. Generally, in every lesson, teacher solved mathematical problems and students copied that down from board and later students were engaged in practicing the process of solution. In no cases, verbal interpretation of their own understanding of mathematical concept was asked by the teachers. Neither teachers' encouragement in students' critical thinking, nor teachers' effort in creating situations for students to develop mental structures on mathematical concept was observed in lessons. Unfortunately, teaching was observed as explaining, lecturing and attempting to convey mathematical knowledge to students not as making mathematics meaningful to them.

\subsection{Limited scope for developing mathematical literacy}

Finally, it is identified that both textbook and teaching did not involve students in logical and systematic thinking (i.e., complex reasoning) as seen in PISA task in Table 1. Eventually, limited scope for students in developing mathematical literacy was identified in this study.

Overall findings for RQ1 and RQ2 are summarized in Table 4 and Table 5 respectively:

Table 4. Overall Findings for RQ1

\begin{tabular}{|c|c|c|}
\hline Themes & \multicolumn{1}{c|}{ Findings } \\
\hline $\begin{array}{c}\text { Making Language } \\
\text { Meaningful to Students }\end{array}$ & $\bullet \begin{array}{l}\text { Teachers agreed that it is important to explain difficult words in } \\
\text { mathematics lessons, however, practice only in specific cases. } \\
\text { Teachers only explained difficult mathematical terms (such as 'cost } \\
\text { price', 'retail selling price') in specific arithmetic lessons. } \\
\text { Teachers usually were not concern in explaining unfamiliar terms or } \\
\text { words (such as 'middle term factorization', 'diagonal', 'bisection', } \\
\text { 'Fibonacci') in algebra and geometry lessons. }\end{array}$ \\
\hline $\begin{array}{c}\text { Contextualization and } \\
\text { Situational Relevancy of }\end{array}$ & $\begin{array}{l}\text { Occasionally, teacher used everyday example in explaining terms } \\
\text { like 'pie chart'. }\end{array}$ \\
\hline Mathematical Problems & $\begin{array}{l}\text { Immediate and direct experiences in students' day to day interaction } \\
\text { with the outside world was not observed in general. } \\
\text { Textbook problems related to application of mathematics to the } \\
\text { situation of natural world faced by many young kids at school, work } \\
\text { station or in family were not found as seen in PISA task in Table 1. }\end{array}$ \\
\hline 'Mathematisation' & $\bullet \begin{array}{l}\text { Students were not engaged in transforming real-world problem into } \\
\text { a mathematical problem. } \\
\text { Both lesson and textbook did not provide the opportunity for } \\
\text { students to make sense of the mathematical situations in terms of the } \\
\text { real situation. }\end{array}$ \\
\hline
\end{tabular}




\begin{tabular}{|c|c|}
\hline $\begin{array}{l}\text { 'Making Better Use' of } \\
\text { Mathematics Textbook }\end{array}$ & $\begin{array}{l}\text { - Teachers rely on textbook as in "adhering" level of usage with no } \\
\text { adjustment or modification. } \\
\text { - } \\
\text { Most of the teachers viewed that textbook examples were not } \\
\text { enough for students' learning. } \\
\text { In no cases teachers took advantage of other sources (such as } \\
\text { technology) to amplify the questions, tasks and exercises given in } \\
\text { textbooks. } \\
\text { In rare cases teachers kept critical eye on textbooks to identify } \\
\text { limitations in order to optimize learning. }\end{array}$ \\
\hline $\begin{array}{c}\text { Teaching in Making } \\
\text { Mathematics } \\
\text { Meaningful }\end{array}$ & $\begin{array}{l}\text { - Without any exception, students were listeners and observers in their } \\
\text { mathematics lessons. } \\
\text { - In no cases, verbal interpretation of their own understanding of } \\
\text { mathematical concept was asked by the teachers. } \\
\text { Neither, teachers' encouragement in students' critical thinking, nor } \\
\text { teachers' effort in creating situations for students to develop mental } \\
\text { structures on any mathematical concept was observed in lessons. } \\
\text { Teaching was observed as explaining, lecturing and attempting to } \\
\text { convey mathematical knowledge to students not as making } \\
\text { mathematics meaningful to them. }\end{array}$ \\
\hline $\begin{array}{c}\text { Developing } \\
\text { Mathematical Literacy }\end{array}$ & $\begin{array}{l}\text { - Both textbook and teaching did not involve students in logical } \\
\text { and systematic reasoning. }\end{array}$ \\
\hline
\end{tabular}

Table 5. Overall Findings for RQ2

\begin{tabular}{|c|ll|}
\hline Issues & & \multicolumn{1}{c|}{ Findings } \\
\hline Time management & $\bullet$ & $\begin{array}{l}\text { Class duration is a challenge in terms of linking real-life related } \\
\text { problem with mathematical content. }\end{array}$ \\
\hline Nature of content & $\bullet$ & $\begin{array}{l}\text { It is difficult for the teachers to connect real-life examples with } \\
\text { algebra and geometry. }\end{array}$ \\
& $\bullet$ & $\begin{array}{l}\text { It is difficult because of the nature of content. } \\
\text { Uninteresting textbook } \\
\text { examples }\end{array}$ \\
$\begin{array}{c}\text { Completing syllabus } \\
\text { within short period of } \\
\text { time }\end{array}$ & $\bullet$ & $\begin{array}{l}\text { Textbook examples are simple and uninteresting for Grade } 8 \\
\text { students. } \\
\text { Textbook examples do not motivate students. }\end{array}$ \\
\hline & $\bullet$ & $\begin{array}{l}\text { Teachers need to complete syllabus within a short period of time. } \\
\text { short period of time. }\end{array}$ \\
\hline
\end{tabular}

\section{Conclusion}

This study finds that teachers emphasize on explaining mathematical concepts in ways that make sense to students but practice in specific cases. Occasionally, students struggle with mathematical terminologies while teachers are unaware of it. Besides, teachers find difficulties to connect some mathematical content with real-life situations because of the nature of content and during lessons they rely on "teaching textbooks" due to time constraint. Both teachers and students in this study identify textbook examples and problems as not interesting. Finally, this study also finds that Grade 8 mathematics textbook in limited cases deals with "real" problems: problems that are typically placed in a "situation".

\section{Recommendation}

The finding of textbook examples and problems as uninteresting to both students and teachers needs attention and further investigation since reviewing literature in this study reveals that when mathematics textbooks are monotonous and uninteresting then it is an obstacle for students learning (Johansson, 2006). Ultimately, in linking 
real-life situation with content of school mathematics at secondary level, development of textbook in dealing with "real" problems placed in a "situation" is required in Bangladesh.

\section{References}

Adams, T. L., Thangata, F., \& King, C. (2005). "Weigh" to Go! Exploring Mathematical Language. MathematicsTeaching in the Middle School, 10(9), 444-448.

Arthur, Y. D., Owusu, E. K., Asiedu-Addo, S., \& Arhin, A. K. (2018). Connecting Mathematics To Real Life Problems: A Teaching Quality That Improves Students' Mathematics Interest. Journal of Research \& Method in Education, 8(4), 65-71.

Bangladesh Bureau of Educational Information and Statistics (BANBEIS) (2008). Study on Qualification and training of non-government Secondary Schools English and Mathematics Teachers and Their Familiarity with Existing Curriculum. (BANBEIS publication no. 372), Ministry of Education, Dhaka.

Bell, J. (2005). Doing your Research Project (4th ed.). New York: Open University press. Retrieved from http://dx.doi.org/10.1191/1478088706qp063oa.

Blum, W., \& Ferri R. B. (2009). Mathematical Modelling: Can It Be Taught and Learnt? Journal of Mathematical Modelling and Application, 1(1), 45-58.

Braun, V., \& Clarke, V. (2006). Using thematic analysis in psychology. Qualitative Research in Psychology, 3(2), 77-101.

Burkhardt, H. (2008). Making mathematical literacy a reality in classrooms. In D. Pitta-Pantazi \& G. Pilippou (Eds.), Proceedings of the Fifth Congress of the European Society for Research in Mathematics Education (pp. 2090-2100). Larnaca, Cyprus: University of Cyprus.

Cheng, L. P. (2013). The design of a mathematics problem using real-life context for young children. Journal of Science and Mathematics Education in Southeast Asia, 36(1), 23-43.

Cohen, P. C. (2001). Democracy and the Numerate Citizen: Quantitative Literacy in Historical Perspective, in L.A.

Cooper, B., \& Harries, V. (2005). Making Sense of Realistic Word Problems: Portraying Working Class "Failure" in a Division with Remainder Problem. International Journal of Research \& Method in Education.

Creswell, J. W. (2012). Educational research: Planning, conducting, and evaluating quantitative and qualitative research (3rd ed.). New Jersey: Pearson Education, Inc.

Diggs, V. (2009). Ask--Think--Create: The Process of Inquiry. Knowledge Quest, 37(5), 30-33.

Eby, J. W., Herrell, A. L., \& Jordan, M. L. (2005). Teaching K-12 Schools: A Reflective Action Approach. Englewood Cliffs, NJ: Prentice Hall.

Franchini, E., Lemmo, A., \& Sbaragli, S. (2017). The role of text comprehension in the mathematization and modeling process. Didactics of Mathematics. From Research to Classroom Practices, 1, 38 - 63.

Frejd, P. (2012). Teachers' conceptions of mathematical modelling at Swedish Upper Secondary school. Journal of Mathematical Modelling and Application, 1(5), 17-40.

Gainsburg, J. (2008). Real-world connections in secondary mathematics teaching. Journal of Mathematics Teacher Education, 11(3), 199-219.

Gough, J. (2007). Conceptual complexity and apparent contradictions in mathematics language. Australian Mathematics Teacher, 63(2), 8-16.

Guo, X. (2001). From 'Bible' to 'material': Argument on the transformation of teachers' view of textbook. Higher Teacher Education Research, 6, 17-21.

Jameel, H. T., \& Ali, H. H. (2016). Causes of Poor Performance in Mathematics from Teachers, Parents and Student's Perspective. American Scientific Research Journal for Engineering, Technology, and Sciences, 15(1), 122-136.

Johansson, M. (2006). Teaching Mathematics with Textbooks: A Classroom and curricular Perspective. Luleå University of Technology, Luleå.

Larina, G. (2016). Analysis of Real-World Math Problems: Theoretical Model and Classroom Application. VoprosyObrazovaniya/ Educational Studies. 2016(3), 151-168, Moscow. 
Lessani, A., Yunus, A. S. M., \& Bakar, K. B. A. (2017). Comparison of New Mathematics Teaching Methods with Traditional Method. International Journal of Social Sciences, 3(2), 1285-1297.

Lockheed, M. E., Vail, S. C., \& Fuller, B. (1986). How Textbooks Affect Achievement in Developing Countries: Evidence from Thailand. Educational Evaluation and Policy Analysis, 8(4), 379-392.

Meiers, M. (2010). Language in the mathematics classroom. The Digest, NSWIT.

Mensah, J. K., Okyere, M., \& Kuranchie, A. (2013). Student attitude towards Mathematics and performance: Does the teacher attitude matter? Journal of Education and Practice, 4(3), 132-139.

National Council of Teachers of Mathematics (NCTM) (1980). An Agenda for Action: Recommendations for School Mathematics of the 1980s. Reston: NCTM.

NCTM (2000). The role of technology in the teaching and learning of Mathematics. Retrieved from http://www.nctm.org/about/content.aspx?id=14233.

National Curriculum and Textbook Board (NCTB) (2012). National Curriculum 2012: Mathematics (class 6-10) and Higher Mathematics (9-10) (in Bengali: mother language of Bangladesh). Dhaka: NCTB.

Nicol, C. C., \& Crespo S. M. (2006). Learning to teach with mathematics textbooks: how pre-service teachers interpret and use curriculum materials. Educational Studies in Mathematics, 62, 331-355.

Organisation for Economic Co-operation and Development (OECD) (2003). The PISA 2003 Assessment Framework: Mathematics, Reading, Science and Problem Solving Knowledge and Skills, PISA, Paris: OECD.

OECD (2009). Learning Mathematics for Life: A Perspective from PISA, Paris: OECD.

OECD (2013). PISA 2012. Assessment and Analytical Framework: Mathematics, Reading, Science, Problem Solving and Financial Literacy, Paris: OECD.

OECD (2017), PISA 2015 Assessment and Analytical Framework: Science, Reading, Mathematics, Financial Literacy and Collaborative Problem solving, revised edition, PISA, Paris: OECD.

Pais, A. (2013). An ideology critique of the use-value of mathematics. Educational Studies in Mathematics, 84(1), $15-34$.

Palm, T. (2006). Word Problems as Simulations of Real-World Situations: A Proposed Framework. For the Learning of Mathematics, 26(1), 42-47.

Palm, T. (2008). Performance Assessment and Authentic Assessment: A Conceptual Analysis of the Literature. Practical Assessment, Research, and Evaluation, 13(4). doi: https://doi.org/10.7275/0qpc-ws45

Qi, C., Zhang, X., \& Huang D. (2014). Research on Textbooks used in China for Teaching Geometric Transformations in Secondary School: From the Perspective of the Teachers' Role. Proceedings of the international conference on Mathematics Textbook Research and Development, 29-31 July 2014, The University of Southampton, UK.

The Royal Ministry of Education, Research and Church Affairs (RMERC) (1999). The Curriculum for the 10-year Compulsory School in Norway, Oslo.

Steen, L. A. (Ed). (2002). Mathematics and Democracy: the case for quantitative literacy, the National Council on Education and the Disciplines (NCED), USA.

Tarmizi, R. A., \& Bayat, S. (2012). Collaborative problem-based learning in mathematics: A cognitive load perspective. Procedia-Social and Behavioral Sciences, Vol. 32, 344-350.

White-Clark, R., DiCarlo, M., \& Gilchriest, N. S. (2008). "Guide on the Side": An Instructional Approach to Meet Mathematics Standards. The High School Journal, 91(4), 40-44.

\section{Notes}

Note 1. Interview Schedule

Questions related to use of language in mathematics

1. Is there any mathematical term /word in textbook or lesson that is unfamiliar to students?

2. If yes, can you give some examples?

3. If students cannot understand any mathematical word/term what do you do? 
Questions related to contextual relevancy

1. Do you think that linking real-life situation with mathematical content is important?

2. If yes, then please explain the reason?

3. Do you use real-life examples and problems in your lessons?

4. Do you use textbook examples only or examples beyond textbook?

5. Why do you do that?

Questions related to situational relevancy

1. Do you think math textbook has enough real-life related examples and problems?

2. Do you think that problems used in textbook are helpful for students in everyday life?

3. Do you think real-life examples are needed for every mathematical content?

4. Why do you think that?

Questions related to challenges that teachers' face

1. What are the difficulties/challenges to link real-life situation with mathematical content?

3. In which content you face more difficulties? (Arithmetic, algebra, geometry)

4. What are the influences of real-life problems on students' learning? Why? 